\title{
Phytoextraction of mercury (Hg) in soils contaminated by button batteries using Bamboo "Bamnusoideae"
}

\section{Fitoextracción de mercurio (Hg) en suelos contaminados por pilas botón empleando Bambú "Bamnusoideae"}

\author{
SECUNDINO-LÓPEZ, Mitzi Gabriela†, GALICIA-LUIS, Laura and LOZANO-CAMARGO, Maria \\ Luisa*
}

Tecnológico de Estudios Superiores del Oriente del Estado de México, dpto. Ingeniería Ambiental, Paraje San Isidro S/N, Barrio de Tecamachalco, Los Reyes La Paz, Estado de México. C.P. 56400 México

Universidad Autónoma Metropolitana-Iztapalapa, Dpto. de Química. Av. Michoacán y la Purísima, Col. Vicentina C.P. 09340, México.

ID $1^{\text {st }}$ Author: Mitzi Gabriela, Secundino-López / ORD ID: 0000-0002-2432-454X

ID $1^{\text {st }}$ Co-author: Laura, Galicia-Luis / CVU CONACYT ID: 120121

ID $2^{\text {nd }}$ Co-author: Maria Luisa, Lozano-Camargo / ORD ID: 0000-0002-0777-6392, CVU CONACYT ID: 46638

DOI: $10.35429 /$ JOIE.2021.17.5.14.19

Received March 13, 2021; Accepted June 30, 2021

\begin{abstract}
The pollution of the planet has generated a series of problems for the environment and human health, such as the case of soils contaminated by heavy metals from batteries that are improperly disposed of in domestic garbage and sanitary landfills; Button batteries ( $\mathrm{HgO})$ pollute the soil, since mercury is very persistent in the environment due to its biomagnification and its great capacity to accumulate in organisms causing diseases in humans at the skin level, respiratory tract, digestive system, etc. . this being a highly toxic metal worldwide. The accumulation of $\mathrm{Hg}$ in soils depends on physicochemical factors such as $\mathrm{pH}$, redox potential, organic matter, and clay. The main objective of this research work is to implement mercury phytoextraction in soils contaminated by button cells, using "Bamnusoideae" Bamboo, a UV-Vis spectroscopic study was carried out to determine the desorption of $\mathrm{Hg}$ from the contaminated soil, images of the stem were obtained, leaves and roots of bamboo without contamination and contaminated with $\mathrm{Hg}$ with a VE-B6 microscope, rating: $85 \mathrm{~V}$ to $265 \mathrm{~V} 50 / 60 \mathrm{~Hz}$, Halogen Lamp: 12V 30W, and the pH of the contaminated soil was measured.
\end{abstract}

Phytoextraction, Button batteries, Bamboo "Bamnusoideae"

\section{Resumen}

La contaminación del planeta ha generado una serie de problemas al medio ambiente y salud humana, tal es el caso de los suelos contaminados por metales pesados provenientes de las pilas descartadas inadecuadamente en la basura doméstica y rellenos sanitarios; las pilas botón $(\mathrm{HgO})$ contaminan el suelo, ya que el mercurio, es muy persistente en el medio ambiente por su biomagnificación y su gran capacidad de acumularse en los organismos causando enfermedades en el ser humano a nivel cutáneo, vías respiratorias, aparato digestivo etc. siendo este un metal altamente tóxico a nivel mundial. La acumulación del $\mathrm{Hg}$ en los suelos depende de los factores fisicoquímicos como $\mathrm{pH}$, potencial redox, materia orgánica y arcilla. Este trabajo de investigación tiene como objetivo principal implementar la fitoextracción de mercurio en suelos contaminados por pilas botón, empleando Bambú "Bamnusoideae", se realizó un estudio espectroscópico UV-Vis para determinar la desorción de $\mathrm{Hg}$ de la tierra contaminada, se obtuvieron imágenes del tallo, hojas y raíz del bambú sin contaminar y contaminado con $\mathrm{Hg}$ con un microscopio VE-B6, rating: $85 \mathrm{~V}$ a to $265 \mathrm{~V}$ 50/60 Hz, Halogen Lamp: 12V 30W, y se midió el pH de la tierra contaminada.

Fitoextracción, Pilas botón, Bambú "Bamnusoideae"

Citation: SECUNDINO-LÓPEZ, Mitzi Gabriela, GALICIA-LUIS, Laura and LOZANO-CAMARGO, Maria Luisa. Phytoextraction of mercury $(\mathrm{Hg})$ in soils contaminated by button batteries using Bamboo "Bamnusoideae". Journal of Innovative Engineering. 2021. 5-17: 14-19

\footnotetext{
*Correspondence to Author (e-mail: maria.lozano@tesoem.edu.mx)

$\uparrow$ Researcher contributing as first Author.
} 


\section{Introduction}

In recent decades, technological-industrial development has increased worldwide, offering a better quality of life to the population, however, energy expenditure, food production, etc., have caused environmental pollution (Bertheau, 2011). The contamination and degradation of natural resources, such as the soil, represents a great problem due to the serious impacts that are had on the environment and human health by heavy metals, which are highly toxic such is the case of mercury, although it has various uses to industrial level either for electricity, chemical mining, metallurgy and electrical.

In the electrical and electronic industry, it is used for its great ability to conduct electricity, the manufacture of button cells and/or mercury oxide $(\mathrm{HgO})$ batteries, presents a long-term energy storage stability, for which they are used in portable devices (radios, toys, headphones, watches) (Weinberg, 2010). However, at the end of their useful life cycle, they are irrationally discarded to the common garbage dump and sanitary landfills were when they meet climatic factors (air, temperature, and water), their internal components begin to react, which are highly damaging to the environment. environment and human health, the accumulation of mercury in soils depends on the physical-chemical factors such as $\mathrm{pH}$, Eh, organic matter, chlorine ions, and oxides of $\mathrm{Fe}$ and Mn (Lindsay 1979, Andersson 1979, Schuster 1991)

So scientists have been given the task in recent years of looking for viable and environmentally friendly alternatives to eliminate the mercury present in soils some of the in situ thermal desorption treatment techniques that physically separate pollutants from the soil by increase the temperature from 600 to $800^{\circ} \mathrm{C}$ obtaining gaseous mercury for purification and recovery (Kucharski et al., 2005); soil washing that involves the extraction of contaminants from the soil; Vitrification performs a heating of the pollutants until reaching the melting point and cools to have a solidified chemically inert glassy mass and immobilize the pollutants (Dermont, G., et al., 2008);
Solidification / Stabilization reduces the mobility of pollutants, encapsulating them in a matrix (solidification) is used when there are mercury concentrations lower than $260 \mathrm{mg} / \mathrm{kg}$ (Mahbub, 2017); Nanotechnology uses iron sulfate $(\mathrm{FeS})$ particles with a nanoparticle size of $1-1 \mathrm{~nm}$, thus reducing the mobility, toxicity and bioavailability of pollutants (Carbrejo at. el., 2010); Phytoremediation which includes emerging techniques using different species of plants, in figure 1, a scheme of the three types of remediation that exist for mercury contamination is shown when using phytoremediation, which are: Phytostability where the roots of the plants immobilize and reduce the bioavailability of the pollutant through biochemical processes that take place in the roots or their surroundings (Dermont et. al., 2008);

Phytoextraction allows the pollutants to be captured by the roots and transported to the organs of the plant (stem and leaves), for their subsequent extraction and destruction or recycling, removing the metal from the soil (Wang, 2012);

Phytovolatization transfers pollutants from the soil to the atmosphere, using plants as intermediaries where metals are absorbed by the roots, transporting them through the xylem and subsequently released from cell tissues to the atmosphere, the most efficient of these processes is phytoextraction by remove the contaminant from the soil (Lázaro, 2008).

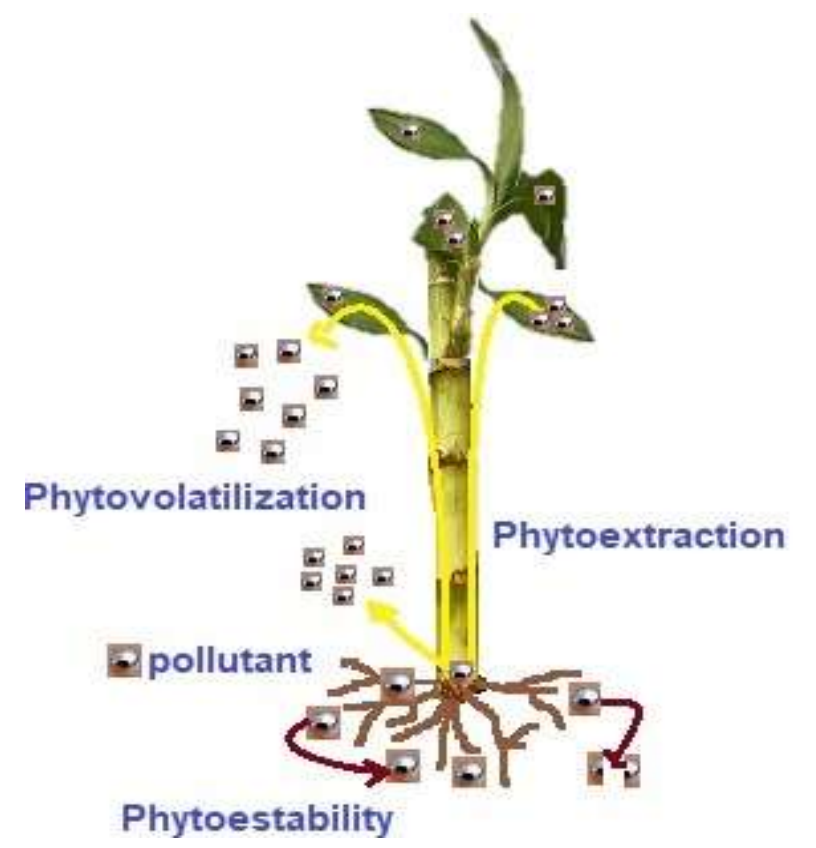

Figure 1 Scheme of the three processes of Phytoremediation of soils contaminated Source: Own Elaboration 


\section{Methodology}

Two "Bambusoideae" bamboo plants were planted, one was placed in a pot without $\mathrm{Hg}$ and the other in a pot contaminated with $\mathrm{Hg}$ from button cells, as shown in figure 2 .

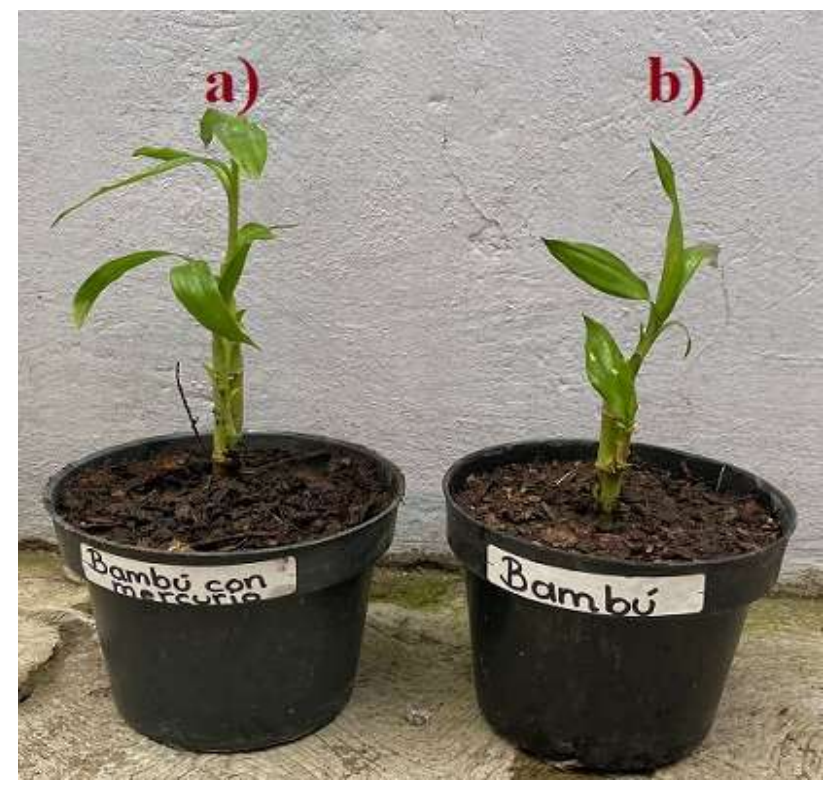

Figure 2 Image of the pots with bamboo, a) soil contaminated with $\mathrm{Hg}$ from button batteries, b) without $\mathrm{Hg}$ Source: Own Elaboration

Subsequently, 1 gram of soil contaminated with $\mathrm{Hg}$ was collected for 65 days, samples of soil contaminated with $\mathrm{Hg}$, and it was placed in a sterilized bottle containing $5 \mathrm{~mL}$ of water, these were perfectly closed and covered with aluminum.

\section{UV-vis spectroscopic study}

The spectroscopic studies were performed using a Perkin-Elmer Lambda 25 UV/Vis spectrometer, which has a tungsten and deuterium lamp, the spectra were obtained from 200 to $500 \mathrm{~nm}$ with a scanning speed of 240 $\mathrm{nm} / \mathrm{min}$

\section{Bamboo images}

Bamboo images were obtained using a VE-B6 microscope, rating: $85 \mathrm{~V}$ to $265 \mathrm{~V} 50 / 60 \mathrm{~Hz}$, Halogen Lamp: 12V 30W, Delay-action Fuse: $1 \mathrm{~A}$.

\section{Results}

\section{$\mathrm{UV}$-Vis spectroscopic study and $\mathrm{pH}$ values}

Table 1 shows the results obtained from the absorbance of $\mathrm{Hg}$ at the wavelength of 253.56 $\mathrm{nm}$ as a function of the time of the contaminated soil samples, as well as the obtained $\mathrm{pH}$ values.

\begin{tabular}{|c|c|r|r|}
$\begin{array}{c}\text { Time/ } \\
\text { days }\end{array}$ & Abs & {$[\mathbf{H g}] / \mathbf{p p m}$} & $\mathbf{p H} \pm \mathbf{0 . 0 5}$ \\
\hline 1 & 0.54129 & 0.217 & 6.51 \\
\hline 2 & 0.51321 & 0.206 & 6.36 \\
\hline 4 & 0.49185 & 0.197 & 6.22 \\
\hline 6 & 0.48630 & 0195 & 7.12 \\
\hline 8 & 0.47872 & 0.192 & 6.25 \\
\hline 10 & 0.46917 & 0.188 & 6.22 \\
\hline 12 & 0.45597 & 0.183 & 6.22 \\
\hline 14 & 0.45320 & 0.181 & 6.29 \\
\hline 21 & 0.35991 & 0.144 & 6.36 \\
\hline 28 & 0.30836 & 0.124 & 6.14 \\
\hline 35 & 0.30617 & 0.123 & 6.22 \\
\hline 49 & 0.28579 & 0.115 & 6.04 \\
\hline 56 & 0.22570 & 0.091 & 6.00 \\
\hline 65 & 0.21511 & 0.086 & 6.25 \\
\hline
\end{tabular}

Table 1 The concentrations, and $\mathrm{pH}$ values of the samples taken from the contaminated substrate are shown Source: Own Elaboration

As can be seen in table 1 , it is clearly shown that there is a decrease in the concentration of $\mathrm{Hg}$ in the contaminated land as a function of time, with mercury concentrations higher than the permissible limits established by the Official Mexican Standard NOM-147SEMARNAT/SSA1-2004 regarding the concentration of soluble pollutants (CRs) that indicates that for mercury it is $0.020 \mathrm{ppm}$, which gives a clear indication of the serious contamination that is had in the soil by button batteries at the end of their life cycle of an inappropriate way.

In graph 1, the absorbances are shown as a function of time for the samples extracted from the substrate, where it is clearly observed that there is desorption of $\mathrm{Hg}$ as the days pass, it is important to clarify that these are the first studies carried out. 


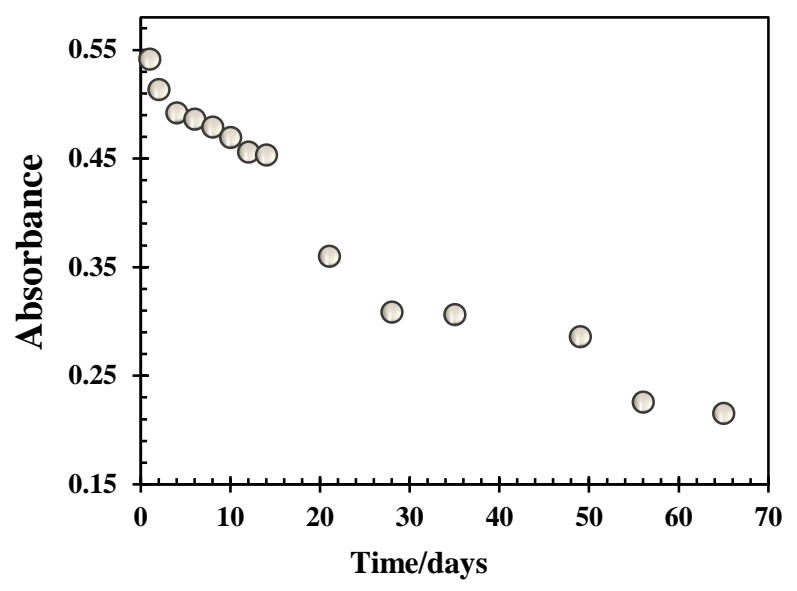

Graphic $1 \mathrm{Hg}$ desorption graph in contaminated soil vs time in days

Source: Own Elaboration

The $\mathrm{pH}$ values obtained in this work indicate that there is a reduction of the $\mathrm{Hg}$ salts to $\mathrm{Hg}^{\circ}$, favorably increasing the loss of $\mathrm{Hg}$ by volatilization since, as reported in the literature by Frear at. the. when the $\mathrm{pH}$ rises from 5.3 to 6.4 there is less volatilization to the environment, according to the analyzes carried out so far it can be established that on earth the predominant species is mercury (II) hydroxide $\left(\mathrm{Hg}(\mathrm{OH})_{2}\right)$, which is a short-lived transitory intermediate in the formation of mercury oxide $(\mathrm{HgO})$ in the alkaline aqueous medium, it has been determined that $\mathrm{Hg}(\mathrm{OH})_{2}$ is a weak base and that it may be accompanied by $\mathrm{HgOH}^{+}$and $\mathrm{Hg}^{2+}$, as shown in figure 3 , distribution diagram of $\mathrm{Hg}$ (II) species as a function of $\mathrm{pH}$ in soils (Adriano, 1986).

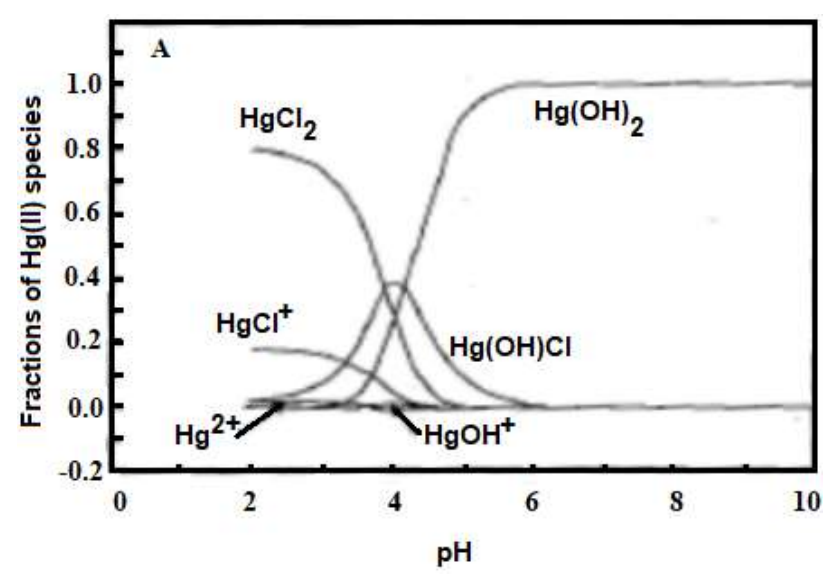

Figure $3 \mathrm{Hg}$ (II) speciation as a function of $\mathrm{pH}$ (Adriano, 1986).

\section{Leaf, stem and root images}

Images of the leaves, stem and root of the bamboo were obtained without and with $\mathrm{Hg}$, using a VE-B6 microscope, in figure 4.
The images obtained from the roots of the bamboo are shown, 4a without mercury and $4 \mathrm{~b}$ with mercury as it can be Observe there is a great difference in the structure of the vascular cylinders found in the stela along with the xylem and phloem in the contaminated root, small clusters are observed changing the structure of the root, which gives evidence of the adhesion of $\mathrm{Hg}$ in it.

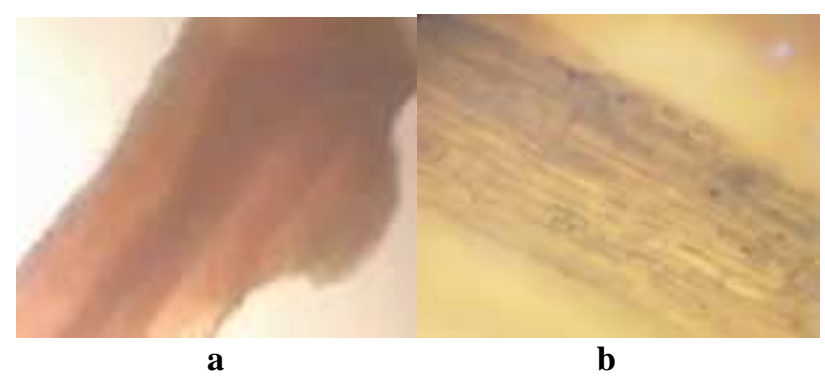

Figure 4 Images of the bamboo root a) without $\mathrm{Hg}$ and b) with $\mathrm{Hg}$

Source: Own Elaboration

In figure 5, the images of the stem are shown, 5 a) without $\mathrm{Hg}$ and $5 \mathrm{~b}$ ) with $\mathrm{Hg}$, as can be seen, there is a clear alteration in the structure of the metaxylem vessel and of the protoxylem vessel in the stem structure when absorbing the $\mathrm{Hg}$.

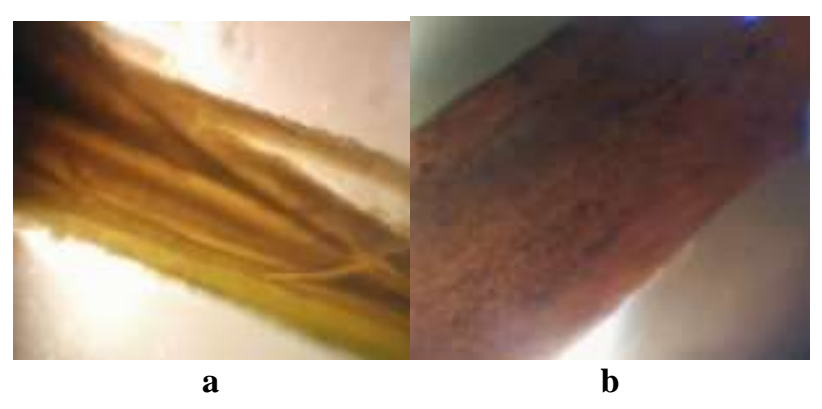

Figure 5, Images of the bamboo root a) without $\mathrm{Hg}$ and b) with $\mathrm{Hg}$

Source: Own Elaboration

In figure 6 , the images of the leaves are shown, 6 a) without $\mathrm{Hg}$ and $6 \mathrm{~b}$ ) with $\mathrm{Hg}$, in figure 5a no change is shown in the structure of the bamboo leaf, only small drops of water are distinguished, in figure $6 \mathrm{~b}$, it can be seen that there is actually an absorption of $\mathrm{Hg}$ in the structure of the sheath and trichomes in the cross-section, observing metallic clusters. 


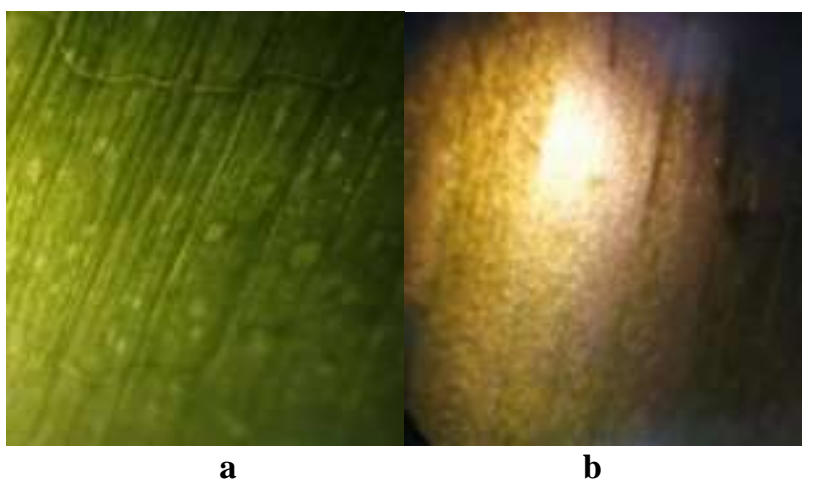

Figure 6 Images of bamboo leaves a) without $\mathrm{Hg}$ and b) with $\mathrm{Hg}$

Source: Own Elaboration

In order to corroborate the presence of mercury in the stem, leaves, and root of the bamboo, a UV-vis spectroscopic study was carried out, for this, acid digestion was carried out on the samples to extract the amount of $\mathrm{Hg}$ contained, the spectrum It was the neighborhood in a wavelength of 200 to $500 \mathrm{~nm}$, observing at $253.56 \mathrm{~nm}$ the absorbance of $\mathrm{Hg}$ in the contaminated samples, in the samples without mercury no absorbance was detected at that length, in table 2 the concentrations of $\mathrm{Hg}$ in the stem, leaves, and root of bamboo.

\begin{tabular}{|c|c|r|r|}
\hline samples & \multicolumn{1}{c}{ Abs } & \multicolumn{1}{c}{$[\mathbf{H g}] / \mathbf{p p m}$} & $\mathbf{p H} \pm \mathbf{0 . 0 5}$ \\
\hline Leaf & 3.1033 & $3.09 \times 10^{-5}$ & 5.32 \\
\hline Stem & 1.0706 & $5.94 \times 10^{-6}$ & 5.65 \\
\hline Root & 1.2037 & $6.68 \times 10^{-6}$ & 5.45 \\
\hline
\end{tabular}

Table $2 \mathrm{Hg}$ concentrations, absorbance and $\mathrm{pH}$ value of leaves, stem, and root

Source: Own Elaboration

The data obtained show that in the stem there is a lower concentration of $\mathrm{Hg}$ than in the root and there is a higher concentration in the leaves, the Bamboo is capable of concentrating and precipitating the $\mathrm{Hg}$ of the soil in the biomass due to its high potential as a phytoremediator being This is a good candidate to capture metal ions through the roots and accumulate these in their stems and leaves in a friendly and economical way without altering the environment and human health, according to the literature the wavelength in UV- Vis at $253.65 \mathrm{~nm}$ there is the presence of inorganic $\mathrm{Hg}$ - this is not susceptible to any of the main mechanisms of dry deposition and has very low solubility in water, elemental mercury is deposited through a series of chemical reactions in the drops of water of the clouds as expressed in the following equations.

$\mathrm{Hg}_{(\mathrm{g})}^{\circ} \rightarrow \mathrm{Hg}_{(\mathrm{aq})}^{\circ}$

$$
\begin{aligned}
& \mathrm{Hg}_{(\mathrm{aq})}^{\circ}+\mathrm{O}_{3} \rightarrow \mathrm{Hg}(\mathrm{II})_{(\mathrm{aq})} \\
& \mathrm{Hg}(\mathrm{II})_{(\mathrm{aq})}+\text { polvo/evaporación } \rightarrow \mathrm{Hg}_{(\mathrm{II})(\mathrm{p})} \\
& \mathrm{Hg}_{(\mathrm{II})(\mathrm{aq})}+\mathrm{SO}_{3}^{2-} \rightarrow \mathrm{Hg}_{(\mathrm{a})}^{\circ}
\end{aligned}
$$

This type of mechanism opens a possible deposition path for elemental mercury present in the atmosphere.

\section{Acknowledgments}

Thanks to the Tecnológico de Estudios Superiores del Oriente del Estado de México and the Universidad Autónoma MetropolitanaIztapalapa for the support received to carry out this project.

\section{Conclusions}

The spectroscopic UV-Vis study allowed identifying that the bamboo "Bamnusoideae" is a good candidate to be used as a phytoremediator of soils contaminated with mercury from discarded button cells, obtaining $\mathrm{Hg}$ concentrations in the root of $6.68 \times 10-6 \mathrm{ppm}$, in the stem 5.9x10-6 ppm and in the leaves $3.09 \times 10-5 \mathrm{ppm}$ and having an average desorption concentration of $\mathrm{Hg}$ in the soil of $14.07 \mathrm{ppm}$. The images obtained in the microscope give clear evidence of the presence of mercury in the root, stem and leaves by changing their morphological structure.

\section{References}

Adriano D. C. 1986. Trace Elements in the Terrestrial Enviroment. Springer-Verlag. 298324. New York (USA).

Andersson, A (1979) Mercury in Soil. In: Nriagu, J.O (Ed.) The Biogeochemistry of Mercury in the Environment. Elsevier, Amsterdam, 79-112.

Cabrejo, E. y Philips E. 2010. In situ remediation and stabilization technologies for mercury in clay soils. Student summer internship technical report

Dermont G., Bergeron M., Mercier G., RicherLafleche M. 2008. Soil Washing for Metal Removal: a Review of Physical/Chemical Technologies and Field Applications, J. Hazard. Mater. 152: 1-31. 
Frear, D., y Dills, L. (1967). Mechanism of the Insecticidal Action of Mercury and Mercury Salts. Journal of Economic Entomology, 60(4), 570-574.

Kucharski, R., Sas-Nowosielska, A., Małkowski, E., Japenga, J., Kuperberg, J. M., Pogrzeba, M., Krzyzak, J. 2005. The use of indigenous plant species and calcium phosphate for the stabilization of highly metal-polluted sites in southern Poland. Plant and Soil. 273: 291- 305.

Lázaro, J. 2008. Fitorremediación de suelos contaminados con metales pesados: Evaluación de plantas tolerantes y optimización del proceso mediante prácticas agronómicas. Tesis de la Universidad Santiago de Compostela. Dpto. de Edafología y Química agrícola.

Lindsay, W.L. (1979) Chemical Equilibria in Soils. John Wiley and Sons, New York, 449.

Mahbub, K., Bahar, M., Labbate, M., Krishnan, K., Andrews, S., Naidu, R., Megharaj, M. 2017. Bioremediation of mercury: not properly exploited in contaminated soils. Appl Microbiol Biotechnol 101:963-976

Wang, J., Feng, X., Anderson, C., Xing, Y., Shang L. 2012. Remediation of Mercury Contaminated Sites. Journal of Hazardous Materials. 221-222: 1-18.

Weinberg, J. (2010). Introducción a la Contaminación por Mercurio para las ONG. Red Internacional de Eliminación de los Contaminantes Orgánicos Persistentes (IPEN), 166. 